\title{
Peningkatan Hasil Belajar Peserta Didik Pada Pembelajaran Matematika Melalui Model Cooperative Learning Tipe Stad di Kelas VI SDN 01/X Rantau Indah Semester Ganjil Tahun Ajaran 2021/2022
}

\author{
Setiarna \\ SDN 01/X Rantau \\ Jl. Rantau Indah, Dendang, Kabupaten Tanjung Jabung Timur, Jambi \\ setiarna@gmail.com
}

\begin{abstract}
This study aims to describe and obtain information on improving learning outcomes of Mathematics learning through Cooperative Learning Type STAD. This research is a classroom action research consisting of two cycles, each cycle consisting of two meetings. Each meeting consists of four stages, namely planning, implementation, observation and reflection. The subjects of this study were students of class VI SDN 01/X Rantau Indah, totaling 18 people. This research was conducted in the odd semester of the 2021/2022 academic year. Data collection techniques using tests, observations, and documentation. Data were analyzed using percentages. The results showed that through the STAD Cooperative Learning Type, it could improve the Mathematics learning outcomes of the VI grade students of SDN 01/X Rantau Indah by replacing group members.
\end{abstract}

Keywords: Learning outcomes, Mathematics, STAD.

\begin{abstract}
Abstrak
Penelitian ini bertujuan untuk mendeskripsikan dan mendapatkan informasi peningkatan hasil belajar pembelajaran Matematika melalui Cooperative Learning Tipe STAD.Penelitian ini merupakan penelitian tindakan kelas yang terdiri dari dua siklus masing-masing siklus terdiri dari dua kali pertemuan. Masingmasing petemuan terdiri dari empat tahapan yaitu perencanaan, pelaksanaan, observasi dan refleksi. Subjek penelitian ini adalah peserta didik kelas VI SDN 01/X Rantau Indahyang berjumlah 18 orang. Penelitian ini dilaksanakan pada semeseter ganjil tahun ajaran 2021/2022. Teknik pengumpulan data menggunakan tes, observasi, dan dokumentasi. Data dianalisis menggunakan persentase. Hasil penelitian menunjukkan bahwa melalui Cooperative Learning Tipe STAD dapat meningkatkan hasil belajar Matematika peserta didik kelas VI SDN 01/X Rantau Indah dengan penggantian anggota kelompok.
\end{abstract}

Kata kunci: Hasil belajar, Matematika, STAD

Copyright (c) 2022 Setiarna

Corresponding author: Setiarna

Email Address: setiarna@gmail.com (Jl. Rantau Indah, Dendang, Kabupaten Tanjung Jabung Timur, Jambi)

Received 10 January 2022, Accepted 16 January 2022, Published 16 February 2022

\section{PENDAHULUAN}

Pendidikan dalam Undang- undang Nomor 20 Tahun 2003 Bab 1 Pasal 1 merupakan usaha sadar dan terencana untuk mewujudkan suasana belajar dan proses pembelajaran agar peserta didik secara aktif mengembangkan potensi dirinya untuk memiliki kekuatan spiritual keagamaan, pengendalian diri, kecerdasan, akhlak mulia, serta keterampilan yang diperlukan dirinya, masyarakat, bangsa dan negara. Dengan demikian, untuk meningkatkan mutu pendidikan perlu dilakukan berbagai inovasi. Pendidikan dalam arti teknis adalah proses dimana masyarakat, melalui lembaga-lembaga pendidikan (sekolah, perguruan tinggi atau lembaga-lembaga lain) dengan sengaja mentransformasikan warisan budayanya, yaitu pengetahuan, nilai-nilai dan keterampilanketerampilan, dari generasi ke generasi (Dwi Siswoyo, dkk, 2008: 18). 
Pendidikan bertujuan untuk menjadikan anak mampu memainkan peran sebagai makhluk individu dan makhluk sosial sesuai dengan potensi yang dimilikinya. Peningkatan kualitas anak ini tidak hanya menjadi tanggung jawab pemerintah saja tetapi juga tanggung jawab orang tua, guru dan lingkungan masyarakat. Proses belajar mengajar adalah suatu proses yang mengandung serangkaian perbuatan guru dan peserta didik atas dasar hubungan timbal balik yang berlangsung dalam situasi edukatif untuk mencapai tujuan tertentu. Interaksi atau hubungan timbal balik antara guru dan peserta didik itu merupakan syarat utama bagi berlangsungnya proses belajar mengajar, dimana guru sebagai fasilitator, dan berpusat pada peserta didik dan setiap guru menginginkan proses pembelajaran yang dilaksanakannya menyenangkan. Peserta didik antusias mengacungkan tangan untuk menjawab pertanyaan atau memberikan pendapat, bertukar informasi, dan saling memberikan informasi.

Menurut Permendiknas Nomor 22 Tahun 2006 tantang Standar Isi, matematika merupakan ilmu universal yang mendasari perkembangan teknologi modern, mempunyai peran penting dalam berbagai displin dan memajukan daya pikir manusia. Perkembangan pesat di bidang teknologi informasi dan komunikasi dewasa ini dilandasi oleh perkembangan matematika dibidang teori bilangan, aljabar, analisis, teori peluang dan matematika diskrit. Untuk mengusasi dan mencipta teknologi di masa depan diperlukan penguasaan matematika yang kuat sejak dini. Mata pelajaran Matematika perlu diberikan kepada semua peserta didik mulai dari sekolah dasar untuk membekali peserta didik dengan kemampuan berpikir logis, analitis, sistematis, kritis, dan kreatif, serta kemampuan bekerjasama. Kompetensi tersebut diperlukan agar peserta didik dapat memiliki kemampuan memperoleh, mengelola, dan memanfaatkan informasi untuk bertahan hidup pada keadaan yang selalu berubah, tidak pasti, dan kompetitif.

Di dunia pendidikan, sekolah adalah merupakan sarana untuk memperoleh pendidikan yang didalamnya terdapat proses pembelajaran. Proses pembelajaran merupakan interaksi antara guru dan peserta didik. Suatu proses pembelajaran akan dapat mencapai hasil seperti yang diharapkan apabila direncanakan dengan baik. Ada tiga hal yang pokok yang perlu diperhatikan dalam Perencanaan Kegiatan Pembelajaran yaitu mulai dari menyusun perencanaan pembelajaran, melaksanakan proses pembelajaran, dan melakukan evaluasi. Materi dan cara pembelajaran diwujudkan dalam bentuk silabus, sedangkan cara mengetahui keberhasilan pembelajaran dapat diwujudkan dalam bentuk sistem penilaian. Berdasarkan Undang-Undang Nomor 14 Tahun 2005 tentang Guru dan Dosen, Guru adalah pendidik professional dengan bertugas melaksanakan itu semua serta mendidik, mengajar, membimbing, mengarahkan, melatih, menilai dan mengevaluasi peserta didik pada anak usia dini jalur pendidikan formal, pendidikan dasar dan pendidikan menengah.

Matematika merupakan salah satu mata pelajaran yang mempunyai andil dalam pembentukan peserta didik dan diharapkan melalui mata pelajaran Matematika peserta didik mampu mengembangkan potensinya secara maksimal sehingga bisa menjadi insan yang cerdas, trampil serta kreatif di dalam kehidupan bermasyarakat. Mata pelajaran matematika bertujuan agar peserta didik memiliki kemampuan yaitu memahami konsep matematika, menjelaskan keterkaitan antarkonsep dan 
Peningkatan Hasil Belajar Peserta Didik Pada Pembelajaran Matematika Melalui Model Cooperative Learning Tipe Stad di Kelas VI SDN 01/X Rantau Indah Semester Ganjil Tahun Ajaran 2021/2022, Setiarna

mengaplikasikan konsep atau algoritma, secara luwes, akurat, efisien, dan tepat, dalam pemecahan masalah.Menggunakan penalaran pada pola dan sifat, melakukan manipulasi matematika dalam membuat generalisasi, menyusun bukti, atau menjelaskan gagasan dan pernyataan matematika.Memecahkan masalah yang meliputi kemampuan meliputi kemampuan memahami masalah, merancang model matematika, menyelesaikan model dan menafsirkan solusi yang diperoleh.Memecahkan masalah yang meliputi kemampuan memahami masalah, merancang model matematika, menyelesaikan model dan menafsirkan solusi yang diperoleh.Mengkomunikasikan gagasan dengan simbol, tabel, diagram, atau media lain untuk menperjelas keadaan atau masalah.

Dari uraian di atas dapat ditarik kesimpulan bahwa pentingnya pendidikan bagi peserta didik salah satunya pendidikan yang mengajarkan matematika, karena setiap aktifitas kehidupan menggunakan matematika, hal tersebutlah yang membuat matematika adalah mata pelajaran yang utama untuk dipelajari bagi peserta didik dan ini juga dibuktikan sejak duduk dibangku tingkat dasar, peserta didik sudah diajarkan mata pelajaran matematika.

Namun pada kenyataannya, sebagian peserta didik menganggap mata pelajaran Matematika merupakan mata pelajaran yang sulit dipahami. Hal ini dapat dilihat berdasarkan hasil nilai ulangan harian mata pelajaranMatematika peserta didik kelas VI SDN 01/X Rantau Indah, Kabupaten Tanjung jabung Timur yang kurang memuaskan. Dari 18 orang kelas VI, hanya 7 orang atau 39\% yang memperoleh nilai mencapai Kriteria Ketuntasan Minimal ( KKM ) yaitu 70.

Berdasarkan atas evaluasi peneliti selama mengajar di SDN 01/X Rantau Indahterdapat beberapa kendala dalam pencapaian hasil belajar yang optimal. Dari beberapa kali diberikan penilaian ternyata hasil belajarnya masih tetap rendah walau telah diberikan berbagai model atau model pembelajaran.Yang menjadi bidang kajian peneliti ini adalah rendahnya hasil belajar peserta didik untuk mata pelajaran Matematika di SDN 01/X Rantau Indah. Untuk meningkatkan hasil belajar peserta didik tersebut secara maksimal, maka perlu perbaikan model pembelajaran yaitu melalui Model Pembelajaran Kooperatif tipe STAD. Pembelajaran Koopratif Tipe STAD yang dimaksud adalah model pembelajaran yang mempersyaratkan peserta didik membentuk kelompok yang beranggotakan empat orang setiap kelompoknya.

Penelitian ini dilakukan untuk memecahkan masalah yang selama ini menyebabkan guru resah, gelisah dengan banyaknya nilai peserta didik tidak tuntas sesuai dengan nilai ketuntasan minimal (KKM). Padahal guru selama ini telah menerapkan yang namanya Pembelajaran kontekstual, dimana pusat pembelajaran sudah berada pada peserta didik dan guru hanya sebagai pemotifator dan fasilitator.

\section{METODE}

Jenis penelitian ini adalah penelitian tindakan kelas. Penelitian ini dilaksanakan di SDN 01/X Rantau Indah pada semester ganjil, tahun ajaran 2021/2022. Subjek dalam penelitian ini adalah siswa VI dengan jumlah peserta didik 18 orang. Prosedur penelitian ini meliputi perencanaan, pelaksanaan, 
pengamatan, dan refleksi. Penelitian ini dilaksanakan dalam dua siklus, masing-masing siklus terdiri dari dua kali pertemuan. Teknik yang digunakan dalam pengumpulan data adalah observasi, tes, catatan lapangan dan dokumentasi. Data dianalisis melalui persentase dan reduksi data.

\section{HASIL DAN DISKUSI}

\section{Siklus I}

1. Perencanaan

Pada tahap ini peneliti mempersiapkan perangkat pembelajaran yang terdiri dari rencana pelajaran 1, LKS 1, bahan ajar, soal tes formatif 1, lembaran observasi dan alat-alat pengajaran yang mendukung.

\section{Pelaksanaan}

Siklus I dilaksanakan selama dua kali pertemuan. Pelaksanaan siklus I dijabarkan berdasarkan perencanaan yang telah diuraikan dan dilaksanakan dalam tiga kegiatan yaitu kegiatan pendahuluan, kegiatan inti, dan kegiatan penutup serta terintegrasi dalam 2 kali pertemuan pertmeuan pertama dilakukan pada hari 7 Oktober 2021, dan peretemuan kedua dilaksanakan pada hari 14 Oktober 2021 Berikut disajikan proses pelaksanaan kegiatan pembelajaran yang telah dilakukan pada siklus I.

Pelaksanaan kegiatan belajar mengajar untuk siklus I dilaksanakan pada tanggal Kamis, 7 Oktober 2021 di Kelas VI dengan jumlah peserta didik 18 orang dengan materi operasi hitung campuran. Dalam hal ini peneliti bertindak sebagai guru. Adapun proses belajar mengajar mengacu pada rencana pelajaran yang telah dipersiapkan yang dilaksanakan dalam tiga kegiatan yaitu kegiatan pendahuluan, kegiatan inti, dan kegiatan penutup. Untuk lebih jelasnya, pelaksanaan pembelajaran diuraikan sebagai berikut.

Pada kegiatan pendahuluan ini guru memberikan salam dan mengajak semua siswa berdo'a menurut agama dan keyakinan masing-masing. Kemudian guru mengajak siswa untuk menyanyikan lagu “Indonesia Raya” bersama-sama. Dilanjutkan lagu Nasional "Bagimu Negeri (Padamu Negeri)". Lalu guru mengecek kesiapan diri dengan mengisi lembar kehadiran dan memeriksa kerapihan pakaian, posisi dan tempat duduk disesuaikan dengan kegiatan pembelajaran dan siswa diajarkan untuk pembiasaan membaca selama 15 menit. Dan terakhir guru menyampaikan tahapan kegiatan yang meliputi kegiatan mengamati, menanya, mengeksplorasi, mengomunikasikan dan menyimpulkan.

Pada kegiatan inti ini guru membagi siswa dalam beberapa kelompok yang masing-masing kelompok terdiri dari 4 orang. Siswa diajak membaca teks dan soal matematika. Guru memberikan waktu 3menit untuk memahami bacaan.Siswa mengerjakan soal berikut bersama teman, Apabila bilangan 160.800.000 ditulis pada tabel nilai tempat, di manakah angka 1 dan 6 ditempatkan?. Guru meminta siswa untuk mendiskusikan jawabannya di dalam kelompoknya lalu meminta setiap perwakilan kelompok untuk menyampaikan hasilnya. Guru memberi kesempatan kepada siswa untuk memberikan masukan, komentar, atau mempertanyakan jawaban teman. 
Peningkatan Hasil Belajar Peserta Didik Pada Pembelajaran Matematika Melalui Model Cooperative Learning Tipe Stad di Kelas VI SDN 01/X Rantau Indah Semester Ganjil Tahun Ajaran 2021/2022, Setiarna

Guru memberikan jawaban apabila dibutuhkan yaitu 160.800 .000 = seratus enam puluh juta delapan ratus ribu. Setelah itu guru menjelaskan tentang tanda pisah angka digunakan untuk bilangan lebih dari 999. Tanda tersebut digunakan untuk memisahkan setiap tiga digit angka dari sebelah kanan urutan angka. Tanda pemisah angka memisahkan kelompok angka ribuan, jutaan, dst. Di Indonesia tanda pemisah angka yang digunakan adalah tanda titik (.). Angka-angka jika dikelompokkan berdasarkan batas tanda pemisah maka akan memiliki kelompok-kelompok angka. Kelompok angka dasar, memiliki tiga angka paling kanan. Kelompok angka ribuan, memiliki tiga angka di sebelah kiri tanda pemisah ribuan. Kelompok angka jutaan, memiliki tiga angka di sebelah kiri tanda pemisah jutaan. Setelah itu setiap kelompok ditugaskan kembali berdiskusi mengenai penjelasan yang diberikan guru, dan kemudian apabila tidak ada yang dimengerti masing-masing kelompok berhak bertanya.

Kegiatan terakhir dalam pertemuan pertama adalah Guru memberikan penguatan materi Bersama-sama siswa membuat kesimpulan/ rangkuman hasil belajar selama sehari. Kemudian Bertanya jawab tentang materi yang telah dipelajari (untuk mengetahui hasil ketercapaian). Guru mengapresiasi hasil kerja siswa dan memberikan motivasi. Guru menyampaikan pesan moral hari ini dengan bijak. Terakhir Salam dan do'a penutup.

Pelaksanaan kegiatan belajar mengajar untuk siklus I dilaksanakan pada hari Kamis, tanggal 14 Oktober 2021 di Kelas VI dengan jumlah peserta didik 18 orang dengan materi operasi hitung campuan. Dalam hal ini peneliti bertindak sebagai guru. Adapun proses belajar mengajar mengacu pada rencana pelajaran yang telah dipersiapkan yang dilaksanakan dalam tiga kegiatan yaitu kegiatan pendahuluan, kegiatan inti, dan kegiatan penutup.

Kegiatan pendahuluan pelaksanaan pembelajaran diawali dengan mengucap salam, Pada kegiatan pendahuluan ini guru memberikan salam dan mengajak semua siswa berdo'a menurut agama dan keyakinan masing-masing. Kemudian guru mengajak siswa untuk menyanyikan lagu "Indonesia Raya" bersama-sama dilanjutkan lagu Nasional "Bagimu Negeri (PadamuNegeri)". Lalu guru mengecek kesiapan diri dengan mengisi lembar kehadiran dan memeriksa kerapihan pakaian, posisi dan tempat duduk disesuaikan dengan kegiatan pembelajaran dan siswa diajarka nuntuk pembiasaan membaca selama 15 menit. Dan terakhir guru menyampaikan tahapan kegiatan yang meliputi kegiatan mengamati, menanya, mengeksplorasi, mengomunikasikan dan menyimpulkan.

Pada kegiatan inti ini guru membagi siswa dalam beberapa kelompok yang masing-masing kelompok terdiri dari 4 orang siswa membaca soal matematika tentang kentang. Pada kegiatan ini siswa harus menemukan bentuk operasi hitung campuran terkait urutan operasi hitungnya. Soal pertama dikerjakan secara individu dan siswa membahasnya dengan teman kelompoknya. Guru meminta seorang siswa untuk menyampaikan hasilnya dan memberi penguatan terkait proses hitungnya. Siswa kemudian diminta untuk membetulkan jawabannya apabila perlu.

Setiap siswa atau dikerjakan dalam kelompok, membuat soal cerita yang melibatkan operasi hitung campuran dan ditukarkan dengan tiga teman atau kelompok.Soal tersebut harus dijawab. Guru 
harus mengece ksoal siswa dan memberimasukan sebelum dijawab. Guru membimbing terkait bentuk operasi hitung campuran. Siswa melakukan perenungan dengan menjawab pertanyaan yang terdapat dalam buku siswa.

Guru dapat menambahkan pertanyaan perenungan berdasarkan panduan yang terdapat pada lampiran di buku guru. Kemudian guru kemudian memberikan penguatan. Siswa mencoba menyelesaikan soal berikut dan mendiskusikan hasilnya dengan teman. Guru memberikanpenguatan.

Siswa melanjutkan kegiatan dengan mengerjakan soal berikut dan menyampaikan hasilnya di depan kelas. Guru dapat meminta siswa lain untuk memberikan komentar dan memberikan penguatan. Selanjutnya siswa berusaha untuk menemukan jawaban soal berikut. Guru meminta salah satu siswa untuk menyampaikan pendapatnya dan siswa lain mengomentari. Guru kemudian memberikan penguatan.

Setelahitu guru menjelaskan langkah operasi hitung adalah selesaikan operasi di dalam kurung, selesaikan perkalian dan pembagian, setelah itu baru selesaikan penjumlahan dan pengurangan.Pada kegiatan penutup pertemuan kedua adalah guru memberikan penguatan materi Bersama-sama siswa membuat kesimpulan/ rangkuman hasil belajar selama sehari. Kemudian bertanya jawab tentang materi yang telah dipelajari (untuk mengetahui hasil ketercapaian). Guru mengapresiasi hasil kerja siswa dan memberikan motivasi. Guru menyampaikan pesan moral hari ini dengan bijak, terakhir Salam dan do'a penutup.

\section{Observasi}

Berikut ini adalah deskripsi data hasil pengamatan hasil belajar peserta didik di kelas VISDN 01/X Rantau Indah pada siklus I. Adapun data hasil penelitian pada siklus I adalah sebagai berikut:

Tabel 1. Rekapitulasi hasil tes formatif Siklus I

\begin{tabular}{|c|c|c|}
\hline No & Uraian & Hasil \\
\hline 1 & Jumlah Nilai & 1245 \\
\hline 2 & Rata-rata Nilai & 69.17 \\
\hline 3 & Peserta didik Tuntas & 12 \\
\hline 4 & Peserta didik Tidak Tuntas & 6 \\
\hline 5 & Persentase Peserta didik Tuntas & $67 \%$ \\
\hline 6 & Persentase Peserta didik Tidak Tuntas & $33 \%$ \\
\hline
\end{tabular}

Dari tabel di atas dapat dijelaskan bahwa dengan menerapkan model pembelajaran STAD diperoleh nilai rata-rata hasil belajar peserta didik adalah 69,17 dan ketuntasan belajar mencapai $67 \%$ atau ada 12 peserta didik dari 18 orang sudah tuntas belajar. Hasil tersebut menunjukkan bahwa pada siklus pertama secara klasikal peserta didik belum tuntas belajar, karena peserta didik yang memperoleh nilai $\geq 70$ hanya sebesar $67 \%$ lebih kecil dari persentase ketuntasan yang dikehendaki yaitu $80 \%$. Hal 
Peningkatan Hasil Belajar Peserta Didik Pada Pembelajaran Matematika Melalui Model Cooperative Learning Tipe Stad di Kelas VI SDN 01/X Rantau Indah Semester Ganjil Tahun Ajaran 2021/2022, Setiarna

ini disebabkan karena peserta didik masih merasa baru dan belum mengerti apa yang dimaksudkan dan digunakan guru dengan menerapkan model pembelajaran STAD.

\section{Refleksi}

Pada tahap refleksi ini peneliti mengadakan diskusi dengan dibantu oleh seorang observer yang bernama Rosidah, S.Pd.SD. tahap refleksi diadakan pada hari Senin, tanggal 18 Oktober 2021 bertempat di kantor SDN 01/X Rantau Indah. Berdasarkan hasil analisis data observasi bersama obsever, dapat disimpulkan refleksi pada siklus I, dengan dua kali pertemuan maka dikemukakan halhal sebagai berikut. Hasil belajar peserta didik masih ada yang belum mencapai ketuntasan, dari hasil tes siklus I ada 6 orang peserta didik yang belum mencapai ketuntasan. Hal ini dikarenakan ada beberapa materi yang belum dikuasai oleh beberapa peserta didik. Untuk itu peneliti meminta peserta didik untuk membaca dan mengulangi lagi materi pelajaran di rumah dan meminta peserta didik untuk mencari informasi sebanyak-banyaknya terkait dengan materi yang dipelajari. Dengan demikian pada siklus II diharapkan hasil belajarnya akan lebih meningkat karena materi telah mereka baca dahulu di rumah. Hal lain juga disebabkan bahwa dalam proses belajar mengajar peserta didik masih banyak yang bermain-main atau tidak fokus dalam belajar. Berdasarkan hal tersebut maka peneliti dan observer berusaha untuk menggunakan waktu semaksimal mungkin agar waktu yang disediakan dapat digunakan sebaik mungkin. Kemudian untuk siklus berikutnya guru memberikan tindakan penggantian anggota kelompok. Untuk itu penelitian ini dilanjutkan ke II atau siklus berikutnya.

\section{SIKLUS II}

\section{Perencanaan}

Pada tahap ini peneliti mempersiapkan perangkat pembelajaran yang terdiri dari rencana pelajaran 1, LKS 1, bahan ajar, soal tes formatif 1, lembaran observasi dan alat-alat pengajaran yang mendukung.

\section{Pelaksanaan}

Siklus I dilaksanakan selama dua kali pertemuan. Pelaksanaan siklus I dijabarkan berdasarkan perencanaan yang telah diuraikan dan dilaksanakan dalam tiga kegiatan yaitu kegiatan pendahuluan, kegiatan inti, dan kegiatan penutup serta terintegrasi dalam 2 kali pertemuan.

Pelaksanaan kegiatan belajar mengajar untuk siklus I dilaksanakan pada tanggal Kamis, 21 Oktober 2021 di Kelas VI dengan jumlah peserta didik 18 orang dengan materi operasi hitung bilangan pecahan. Dalam hal ini peneliti bertindak sebagai guru. Adapun proses belajar mengajar mengacu pada rencana pelajaran yang telah dipersiapkan yang dilaksanakan dalam tiga kegiatan yaitu kegiatan pendahuluan, kegiatan inti, dan kegiatan penutup.

Pada kegiatan pendahuluan ini guru memberikan salam dan mengajak semua siswa berdo'a menurut agama dan keyakinan masing-masing. Menyanyikan lagu "Indonesia Raya" bersama-sama dilanjutkan lagu Nasional "Terima Kasih Kepada Pahlawanku”. Guru mengecek kesiapan diri dengan mengisi lembar kehadiran dan memeriksa kerapihan pakaian, posisi dan tempat duduk disesuaikan 
dengan kegiatan pembelajaran. Pembiasaan membaca 15 menit.Guru menyampaikan tahapan kegiatan yang meliputi kegiatan mengamati, menanya, mengeksplorasi, mengomunikasikan dan menyimpulkan.

Pada kegiatan inti ini siswa kembali dibagi dengan beberapa kelompok berbeda dari siklus I, masing-masing siswa harus mendapatkan kelompok yang berbeda dari siklus I. setelah itu Siswa ditugaskan oleh guru untuk melanjutkan kegiatan dengan membaca soal cerita tentang pecahan dan menjawab pertanyaan. Siswa kemudian mendiskusikan jawabannya dengan teman kelompoknya.Guru meminta salah satu siswa menyampaikan hasilnya dan siswa lain memberikan komentar. Setelah itu guru memberikan penguatan.

Setelah itu siswa kemudian diminta melakukan eksplorasi dengan membuat pecahan baru dan dibuktikan dengan arsiran pada lingkaran.Siswa menyampaikan hasilnya kepada teman kelompoknya.Siswa kemudian mengurutkan pecahan yang ada. Guru mengingatkan kepada siswa untuk membuktikannya dengan gambar.

Kegiatan terakhir/penutup dalam pertemuan pertama adalah guru dan siswa bersama-sama membuat kesimpulan/ rangkuman hasil belajar selama sehari. Kemudian bertanya jawab tentang materi yang telah dipelajari (untuk mengetahui hasil ketercapaian materi). Lalu guru memberi kesempatan kepada siswa untuk menyampaikan pendapatnya tentang pembelajaran yang telah diikuti.

Pelaksanaan kegiatan belajar mengajar untuk siklus I dilaksanakan pada hari Kamis, 28 Oktober 2021 di Kelas VI dengan jumlah peserta didik sebanyak 18 orang dengan materi operasi hitung bilangan pecahan. Dalam hal ini peneliti bertindak sebagai guru.Adapun proses belajar mengajar mengacup ada rencana pelajaran yang telah dipersiapkan yang dilaksanakan dalam tiga kegiatan yaitu kegiatan pendahuluan, kegiatan inti, dan kegiatan penutup. Pada kegiatan pendahuluan ini guru memberikan salam dan mengajak semua siswa berdo'a menurut agama dan keyakinan masing-masing. Menyanyikan lagu "Indonesia Raya" bersama-sama dilanjutkan lagu Nasional "TerimaKasihKepadaPahlawanku". Guru mengecek kesiapan diri dengan mengisi lembar kehadiran dan memeriksa kerapihan pakaian, posisi dan tempat duduk disesuaikandengan kegiatan pembelajaran. Pembiasaan membaca 15 menit. Guru menyampaikan tahapan kegiatan yang meliputi kegiatan mengamati, menanya, mengeksplorasi, mengomunikasikan dan menyimpulkan.

Pada kegiatan inti ini sama seperti pertemuan pertama di siklus II, siswa duduk berdasarkan kelompok yang telah dibagi pada pertemuan I siklus II tersebut. Siswa membaca soal matematika tentang jual beli. Pada kegiatan ini siswa harus menemukan bentuk operasi hitung terkait urutan operasi hitungnya. Soal pertama dikerjakan secara individu dan siswa membahasnya dengan teman kelompoknya. Guru meminta seorang siswa untuk menyampaikan hasilnya dan memberi penguatan terkait proses hitungnya. Siswa kemudian diminta untuk membetulkan jawabannya apabila perlu. Siswa kemudian mengomunikasikan hasilnya melalui tulisan. Guru bisa mengecek pemahaman siswa dengan membaca tulisan. Kegiatan menyelesaikan soal kedua dilakukan dengan cara yang sama seperti di atas. 
Peningkatan Hasil Belajar Peserta Didik Pada Pembelajaran Matematika Melalui Model Cooperative Learning Tipe Stad di Kelas VI SDN 01/X Rantau Indah Semester Ganjil Tahun Ajaran 2021/2022, Setiarna

Kegiatan terakhir/penutup dalam pertemuan pertama adalah guru dan siswa bersama-sama membuat kesimpulan/ rangkuman hasil belajar selama sehari. Kemudian bertanya jawab tentang materi yang telah dipelajari (untuk mengetahui hasil ketercapaian materi). Lalu guru memberi kesempatan kepada siswa untuk menyampaikan pendapatnya tentang pembelajaran yang telah diikuti. Setelah itu dilaksanakan tes.

\section{Observasi}

Pengamatan (observasi) dilaksanakan bersamaan dengan pelaksanaan belajar mengajar. Berikutnya adalah rekapitulasi hasil tes formatif peserta didik terlihat pada tabel berikut.

Tabel 2. Rekapitulasi hasil tes formatif Siklus II

\begin{tabular}{|c|c|c|}
\hline No & Uraian & Hasil \\
\hline 1 & Jumlah Nilai & 1445 \\
\hline 2 & Rata-rata Nilai & 80.28 \\
\hline 3 & Peserta didik Tuntas & 16 \\
\hline 4 & Peserta didik Tidak Tuntas & 2 \\
\hline 5 & Persentase Peserta didik Tuntas & $89 \%$ \\
\hline 6 & Persentase Peserta didik Tidak Tuntas & $11 \%$ \\
\hline
\end{tabular}

Dari tabel di atas diperoleh nilai rata-rata hasil belajar peserta didik adalah 80,28 dan ketuntasan belajar mencapai $89 \%$ atau ada 16 peserta didik dari 18 peserta didik sudah tuntas belajar.

\section{Refleksi}

Tahap refleksi siklus II dilaksanakan pada hari Senin tanggal 1 November 2021 pada jam 11.30 sampai 13.30 dengan dibantu oleh seorang observer yang bernama Rosidah, S.Pd.SD yang bertempat di ruangan majelis guru. Dalam diskusi ini guru dan observer menjelaskan bahwa adanya peningkatan hasil belajar peserta didik dikarenakan adanya tindakan penggantian anggota kelompok pada siklus II. Selain itu peserta didik juga sudah mulai mengerti apa yang dimaksudkan dan dinginkan guru dengan menerapkan model pembelajaran kooperatif tipe STAD. Oleh karena itu penelitian ini tidak dilanjutkan ke siklus berikutnya.

\section{Diskusi}

Tahap refleksi siklus II dilaksanakan pada hari Senin tanggal 1 November 2021 pada jam 11.30 sampai 13.30 dengan dibantu oleh seorang observer yang bernama Rosidah, S.Pd.SD yang bertempat di ruangan majelis guru. Dalam diskusi ini guru dan observer menjelaskan bahwa adanya peningkatan hasil belajar peserta didik dikarenakan adanya tindakan penggantian anggota kelompok pada siklus II. Selain itu peserta didik juga sudah mulai mengerti apa yang dimaksudkan dan dinginkan guru dengan menerapkan model pembelajaran kooperatif tipe STAD. Oleh karena itu penelitian ini tidak dilanjutkan ke siklus berikutnya. 


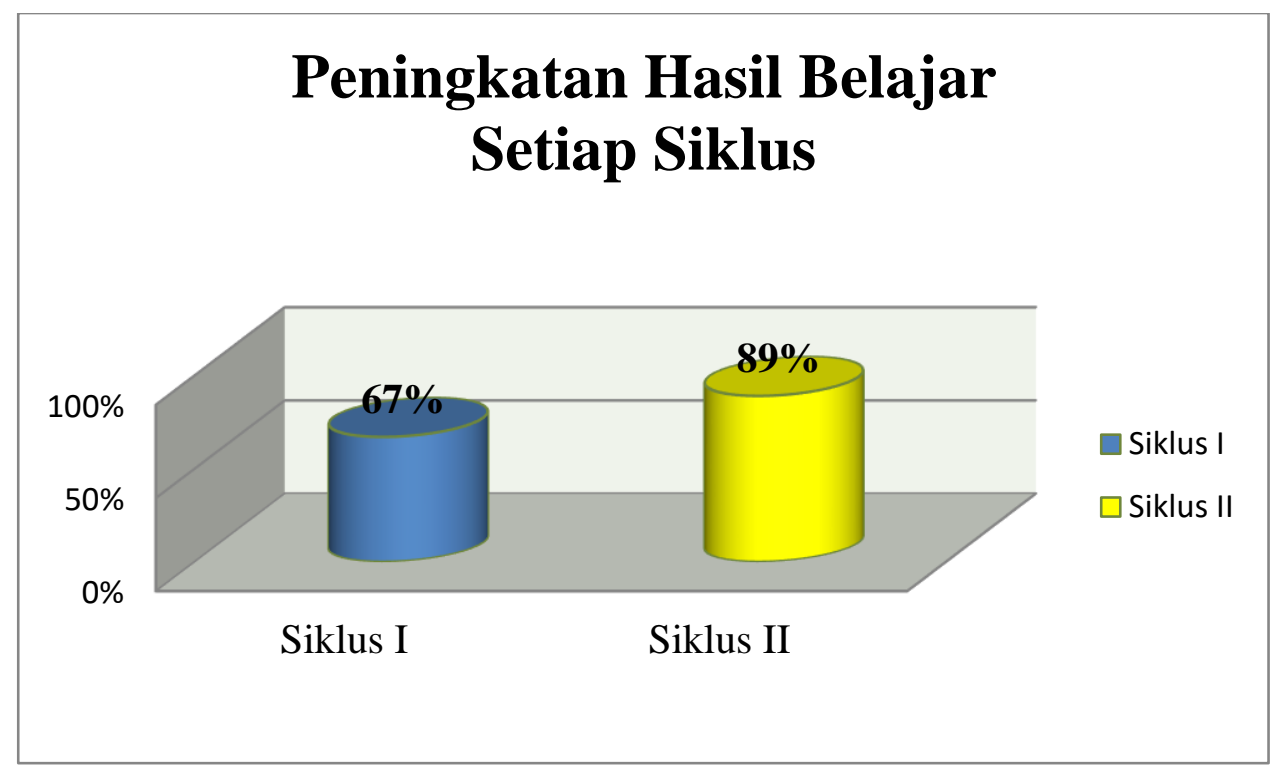

Gambar 4.4. Grafik Peningkatan hasil belajar setiap siklus

\section{KESIMPULAN}

Dari hasil kegiatan pembelajaran yang telah dilakukan selama dua siklus, dan berdasarkan seluruh pembahasan serta analisis yang telah dilakukan dapat disimpulkan sebagai berikut: model pembelajaran STAD memiliki dampak positif dalam meningkatkan hasil belajar peserta didik. Hal ini dapat dilihat dari semakin mantapnya pemahaman peserta didik terhadap materi yang disampaikan guru (ketuntasan belajar meningkat dari siklus I, sampai ke siklus II yaitu masing-masing 67\% dan 89\%. Pada siklus II ketuntasan belajar peserta didik secara klasikal telah tercapai dengan tindakan penggantian anggota kelompok.

Dari hasil penelitian yang diperoleh dari uraian sebelumnya agar proses belajar pembelajaran matematika lebih efektif dan lebih memberikan hasil yang optimal bagi peserta didik, maka disampaikan saran yaitu untuk melaksanakan model pembelajaran STAD memerlukan persiapan yang cukup matang, sehingga guru harus mampu menentukan atau memilih topik yang benar-benar bisa diterapkan dengan model pembelajaran STAD dalam proses belajar mengajar sehingga diperoleh hasil yang optimal. Kemudian dalam rangka meningkatkan prestasi belajar peserta didik, guru hendaknya lebih sering melatih peserta didik dengan berbagai model pengajaran, walau dalam taraf yang sederhana, dimana peserta didik nantinya dapat menemukan pengetahuan baru, memperoleh konsep dan keterampilan, sehingga peserta didik berhasil atau mampu memecahkan masalah-masalah yang dihadapinya. Selain itu perlu adanya penelitian yang lebih lanjut, karena hasil penelitian ini hanya dilakukan di SDN 01/X Rantau Indah tahun pelajaran 2021/2022.Untuk penelitian yang serupa hendaknya dilakukan perbaikan-perbaikan agar diperoleh hasil yang lebih baik. 
Peningkatan Hasil Belajar Peserta Didik Pada Pembelajaran Matematika Melalui Model Cooperative Learning Tipe

\section{REFERENSI}

Ades, Sanjaya. 2011. Model-model Pembelajaran. Jakarta : Bumi Aksara

Agus, Suprijono. 2012. Cooperative Learning: Teori dan Aplikasi Paikem. Yogyakrta: Pustaka Pelajar

A.M Sardiman. 2009. Interaksi dan Motivasi Belajar Mengajar. Jakarta: PT. Rajawali. Pers.

Anita Lie. 2002. Cooperative Learning (Memperaktikan Cooperative Learning di Ruang-Ruang Kelas). Jakarta: PT Gramedia.

A rikunto, Suhardjono, dan Supardi. 2011. Penelitian Tindakan Kelas. Jakarta: PT. Bumi Aksara

Arsyad, Azhar. 2013. Media Pembelajaran. Jakarta: Rajawali Pers.

Darsono, Max. 2000. Belajar dan Pembelajaran. Semarang : CV. IKIP Semarang Press

Kunandar. 2013. Penilaian Autentik (Penilaian Hasil Belajar Peserta Didik berdasarkan Kurikulum 2013). Jakarta:Raja Grafindo Persad

Mulyadi. 2002. Auditing, Edisi keenam, Cetakan pertama. Jakarta: Salemba

Nana Syaodih Sukmadinata. 2005. Landasan Psikologi Proses Pendidikan. Bandung:PT Rosda Karya.

Permendiknas Nomor 22 Tahun 2006 tantang Standar Isi.।

Rusman, 2012.Model-Model Pembelajaran. Bandung : Seri manajemen Sekolah Bermutu.

Slameto. 2010. Belajar dan Faktor-Faktor yang Mempengaruhinya. Jakarta: Rineka Cipta

Slavin, robert E. 2009. Cooperative Learning (Teori, Riset, Praktik). Bandung: Nusa Media.

Sudjana Nana. 2002. Penilaian Hasil Proses Belajar Mengajar. Bandung: Remaja Rosdakarya

Sudjana, Nana . 2009. Penilaian Hasil Proses Belajar Mengajar. Bandung:PT.Remaja Rosdakarya

Trianto. 2009. Mendesain model pembelajaran inovatif-progresif. Jakarta: Kencana Prenada Media Group

Trianto. 2012. Model Pembelajaran Terpadu. Jakarta: PT Bumi Aksara

Undang-Undang Nomor 14 Tahun 2005 tentang Guru dan Dosen

Wina Sanjaya. 2007. Strategi Pembelajaran Berorientasi Standar Proses Pendidikan. Jakarta: Kencana Prenada Media Group.

Wina Sanjaya. 2009. Strategi Pembelajaran. Jakarta: Kencana. 